\title{
Evaluation of some Agricultural Expansion Areas in the Eastern Desert of Egypt using GIS
}

\author{
A.A. Belal", F.S. Moghanm ${ }^{* *}$ and E.E. Mohamed" \\ *Agricultural Applications, Soil and Marine Division, National \\ Authority for Remote Sensing and Space Sciences, Cairo and \\ ** Department of Soil and Water Sciences, Faculty of Agriculture, \\ Kafr El-Sheikh University, Kafr El-Sheikh, Egypt.
}

\begin{abstract}
T AND evaluation for agricultural planning in Asyut, Sohaag and 1 Qena governors was carried out based on soil survey data using remote sensing and geographical information system (GIS). Evaluation of land suitability is one of the most effective methods for proper agricultural land use planning, as it evaluates the suitability of land for a specific crop. The aim of this study is to use GIS and Automated Land Evaluation System (ALES) to assess land capability and crop suitability for various soils and biophysical conditions. The present study was undertaken to demonstrate the usefulness of GIS technologies coupled with soil data to assess crop suitability to achieve sustainable cropping systems in the studied area. As input, the model requires soil data, and for an assessment of the study area, a total of 40 representative soil profiles was used to collect soil samples. The capability evaluation gives four capability orders for agricultural and reclamation land capability (i.e., $\mathrm{C} 1$, good, $\mathrm{C} 2$, moderate, $\mathrm{C} 3$, weak and $\mathrm{N}$, marginal), Moreover, the evaluation model gives four limiting factors suborders, which are topography (t), soils (l) erosion risks (r) and bioclimatic deficiency (b).
\end{abstract}

The suitability of selected field crops indicated that wheat is highly to moderately suitable in different developmental areas. On the other hand, cotton is high to permanent not suitable for different development areas. Suitability of maize is similar to the cotton crop. Selected vegetable crops, potato range from moderately high to permanent not suitable. Tomatoes are high to permanent not suitable. Land suitability of selected fruits, citrus is mainly permanent not suitable for cultivation in different development areas. On the other hand, the date palm and olive trees range from high to permanent not suitable.

Keywords: Agriculture expansion areas, GIS, Land evaluation, ALES program.

e-mail: Belalabd@gmail.com or Belalaz@yahoo.com 
Land evaluation is an approach applied to assess land suitability for a specific use. Land evaluation is itself knowledge-based and requires an extensive knowledge and different conditions to be fulfilled. This can be done automatically by the use of ALES, LECS and GIS systems (Ganzorig and Adyasuren 1995).

Land capability evaluation refers to a range of major kinds of land uses, such as agriculture, forestry, livestock production and recreation. The most widely used categorical systems for evaluating agricultural land is termed land capability classification (Sys et al., 1991).

Land suitability is defined as the fitness of a given type of land for a specified land use type. This can be based on economic and physical metrics. An economic definition of suitability can be based on defined metrics of economic value, e.g., predicted gross margin, net present value, internal rate of return, benefit cost/ratio. A definition of land suitability is more arbitrary, being based on a specified method for combining land quality ratings into an overall rating. The idea is to give the land user a feel for how limiting, or how difficult to manage, the land is for the proposed land use type (Rossiter, 2001).

Land resources won't overcome the needs of such population. So, there is an urgent need to mach land type and uses, in the most practicable and logical ways, to continue sustainable production and to meet the needs of society conserving ecosystems (Abd El-Kawy et al., 2010).

Land evaluation and crop suitability analysis would resolve these issues while providing better land-use options to the farmers. It is known that continued practice of one cropping system type would lead to deteriorating soil health and reduce soil resilience for maintaining productivity by evolving soil allelopathic or growth of deleterious microorganisms in the soil. This causes a yield decline, which cannot be improved with the application of mineral fertilizers (Oz and Friedman, 2001).

Analysis of crop suitability under various systems that could be grown in a given area is essential. Remote sensing (RS) data are used for estimating biophysical parameters and indices besides cropping systems analysis, and landuse and land-cover estimations during different seasons. (Rao et al., 1996 and Panigrahy et al., 2006)

Geographic information systems are powerful tools for data handling, processing and management, and solving environmental problems, but tools can do nothing without methods. (Panigrahy et al., 2006)

Egypt. J. Soil Sci. 54, No. 3 (2014) 
Land capability and suitability maps are confirmed with the mapping units on the physiographic map for producing the productivity map due to: the Agriculture Land Evaluation System for arid and semi arid regions, ALES, has been adapted by (Ismail et al., 2001) to estimate the agriculture land evaluation to ALES-arid is linked directly to its relational database and coupled indirectly with a GIS through the loosely coupled strategy.

Therefore, the objectives of this study are to 1) investigate land evaluation using RS and GIS and to 2) assess the potentiality of soils in the studied area for selecting the best agricultural land use for a particular reclaimable area based on soil quality and water irrigation quality.

\section{Material and Methods}

Study area description

The study area covers a large district between the Nile Valley and the Red Sea. It includes three Governorates, i.e., Asyut, Sohag, and Qena. It includes, as well, a large sector of the Red Sea Governorate (Fig. 1). Sohag - Safaga new highway is considered to be a development investible transportation, road and one of the most important lateral connections between Upper Egypt and the Red Sea and its ports. It begins from Sohag governorate and extends towards the east of the Red Sea until it meets Qena - Safaga road.

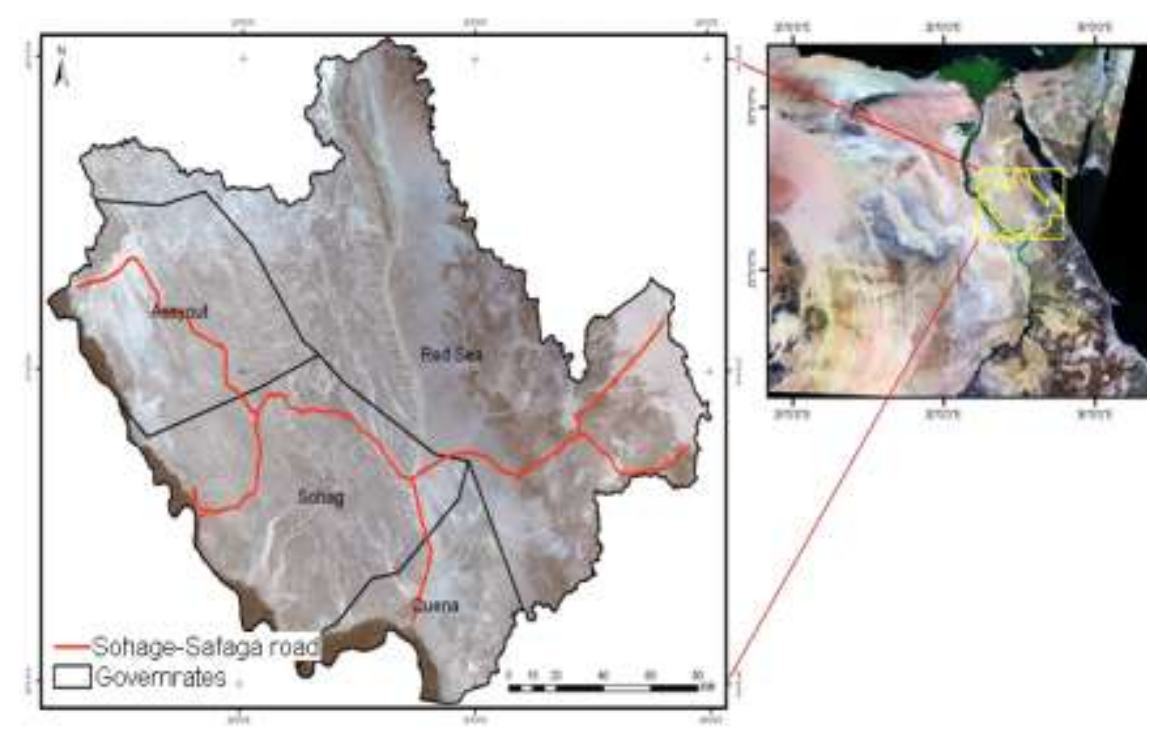

Fig. 1. The study area overlying the four governorates and the road being constructed. 
The maps of land capability and suitability were confirmed with the mapping units on the physiographic map to obtain the map of productivity. The Agriculture Land Evaluation System for arid and semi arid regions, ALES, has been adapted by Ismail et al. (2001) to estimate the agriculture land evaluation. The ALES-arid is linked directly to its relational database and coupled indirectly with a GIS through the loosely coupled strategy. Fig. 2, 3 and 4 show the location of the forty soil profiles obtained in Qena, Assiut and Sohag Governorates.

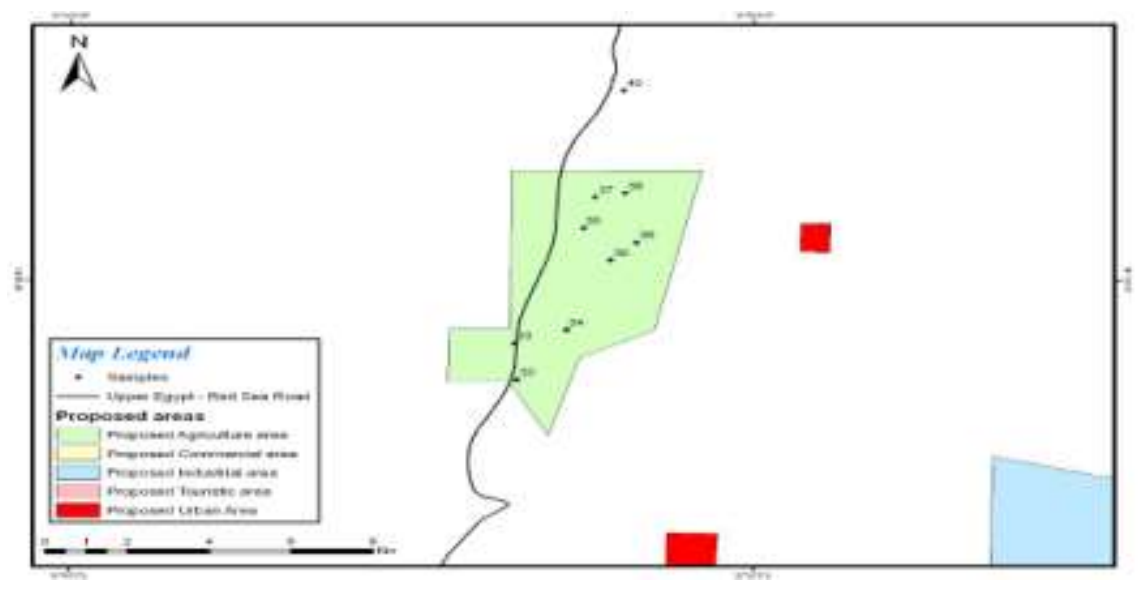

Fig. 2.The proposed agricultural development area in Qena Governorate along with the location of the soil profiles.

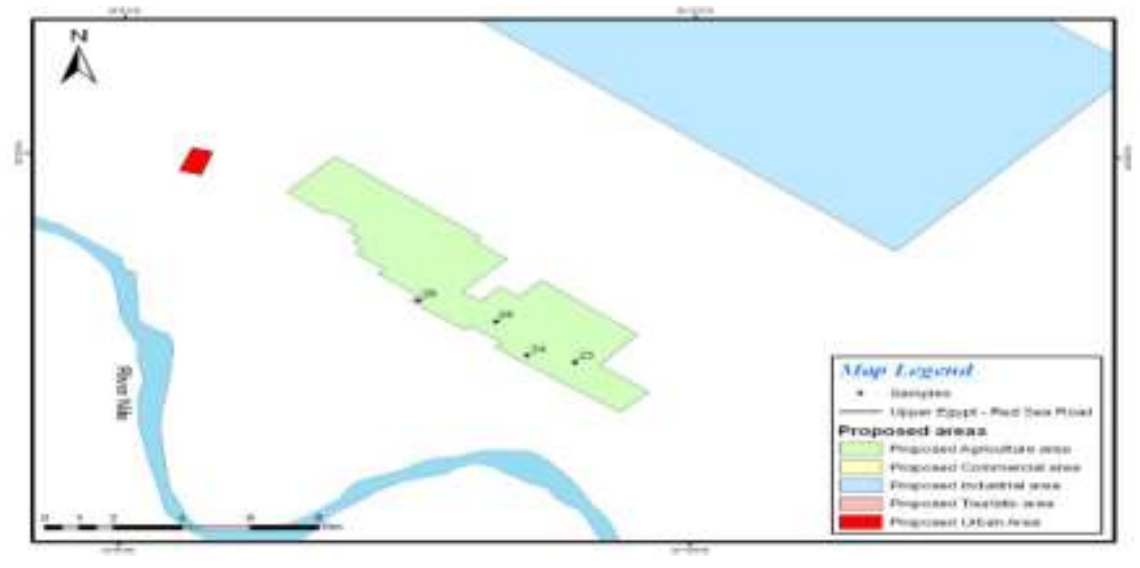

Fig. 3 The proposed agricultural development area in Sohag Governorate along with the location of the soil profiles.

Egypt. J. Soil Sci. 54, No. 3 (2014) 


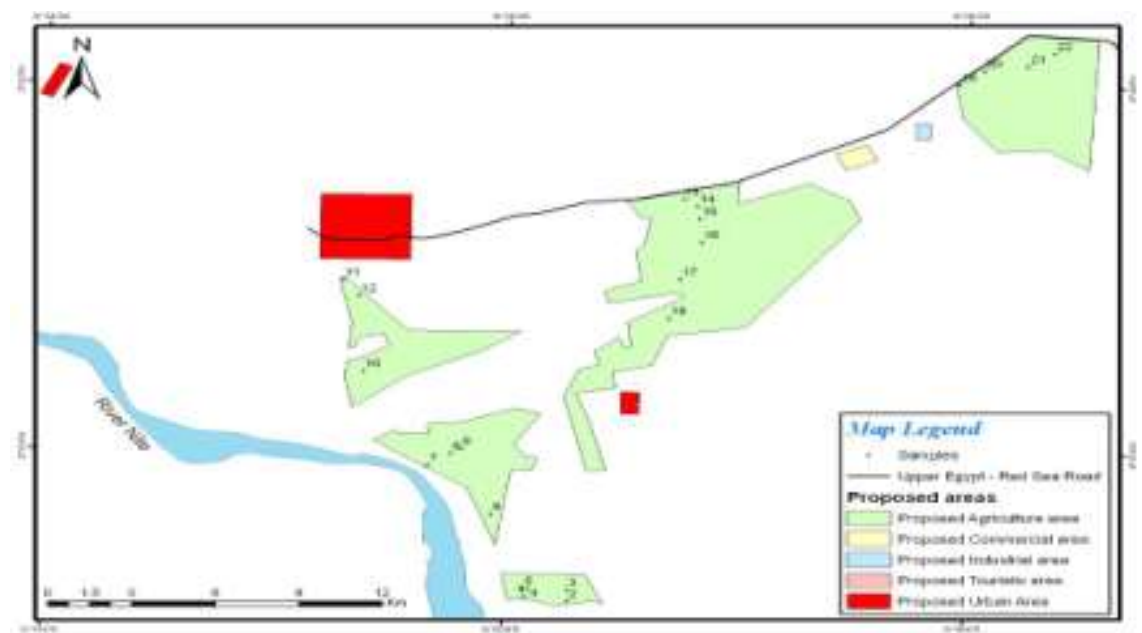

Fig. 4. The proposed agricultural development area in Assiut Governorate along with the location of the soil profiles.

\section{Land capability modeling}

A land capability modeling procedure is applied, following the generally accepted ALES capability. The ALES capability model works interactively, comparing the values of the characteristics of the land-unit to be evaluated with the generalization levels established for each capability class. Following the general accepted of land evaluation (FAO, 1976), the ALES capability model forecasts the general land use capability for a broad series of possible agricultural uses. The methodological criteria refer to the system designed earlier by (Ismail et al., 2001).

Prediction of general land use capability is the result of a qualitative evaluation process or overall interpretation of the following biophysical factors: relief, soil, climate, and current use or vegetation. For each diagnostic criterion or limiting factor, the land characteristics were selected, and the corresponding levels of generalization were established and related with the capability classes by means of gradation matrices. The procedure of maximum limitation was used with matrices of degree to relate the land characteristics directly with capability classes. Matching tables were used and linked to the GIS modeling environment using relational database fields which have identified key attribute property.

A land capability evaluation of the studied area soils was performed, following ALES land capability model.The capability classification procedure is done through matching soil characteristics and qualities with capability limiting factors using the maximum limiting factor method. The capability evaluation includes four capability orders for agriculture and reclamation land capability which are excellent $(\mathrm{C} 1)$, good (C2), moderate (C3) and marginal (N) 
or C4 and C5. Also the evaluation model includes four limiting factors suborders which are topography (t), soils (l), erosion risks (r) and bioclimatic deficiency (b).

\section{Land suitability modeling}

Land suitability evaluation, modeling was applied following the well known ALES suitability model (Ismail et al., 2001). The ALES suitability model is a physical soil suitability evaluation model indicates the degree of suitability for a land use, without respect to economic conditions.

The land use requirements were matched to the land characteristics of each mapping unit to determine its suitability. Depending on the gradations considered for selected criteria (gradation matrices) and on the different agricultural uses. The suitability classes for each crop are: soils with optimum suitability (S1), soils with high suitability (S2) soils with moderate suitability (S3), soils with marginal suitability (S4) and soils with no suitability (S5). The main soil limitations are: useful depth $(\mathrm{p})$, texture $(\mathrm{t})$, drainage condition (d), carbonate content (c), salinity (s), sodium saturation (a) and degree of development of the profile $(\mathrm{g})$. For each diagnostic criterion or limiting factor, the land characteristics were selected, and the corresponding levels of generalization were established and related with the suitability classes by means of gradation matrices. In the suitability model, the evaluation results are presented in the form of a matrix, that is, a two dimensional array with rows, including the soil characteristics and columns consisting of the soil units for which the evaluation was computed. The intersection of the two (i.e., The cells of the matrix) are considered as the result. The overall soil suitability of a soil component (unit) was assessed through the maximum limitation, method where the suitability is taken from the most limiting factor of soil characteristics.

\section{Maps production}

Image processed, surface units, geomorphologic, soils, land capability, land suitability, and agricultural priority maps were layout, annotated, projected and finally produced using Arc GIS software.

\section{The fieldwork and laboratory analyses}

Forty representative soil profiles were chosen according to the variations of color of the corrected Landsat image to verify their soil characteristics. Soil profiles were morphologically described according to the soil morphological map. Disturbed, undisturbed and composted soil samples were collected. The soil samples were collected and dried, sieved and stored in a polyethylene container to be ready for soil characteristic determination as well as physical, chemical and fertility properties. Irrigation, drainage water and water table samples were collected from soil profiles. Laboratory analyses (i.e., Soil texture, $\mathrm{CaCO}_{3}$ content, $\mathrm{CEC}$, EC, ESP, pH, soluble cations and anions, organic matter content and available $\mathrm{N}, \mathrm{P}, \mathrm{K}$ ) were carried out using the soil survey laboratory methods manual (USDA, 2004). 


\section{Geographic information system (GIS)}

ArcGIS $10.1 \odot$ with its ArcGIS Geostatistical and Spatial Analyst extensions (ESRI, 2013) were used for mapping, soil capability and linked ALES land capability model with successively with the aid of some thematic maps.

To study the spatial variability for groundwater/soil characteristics, an interpolation method was used to visually identify patterns of the soil characteristics on two-dimensional data sets. Interpolation between sampling locations was made by the ordinary Kriging interpolation method performed using the Geostatistical Analyst extension available in ESRIC ArcMap $^{\text {TM }}$ v9 (ESRI, 2013).

Ordinary Kriging (Deutsch and Journel, 1992) was used to estimate the value of a continuous soil characteristic $z$ at a non-sampled locations (u) using only the data on this characteristic $[z(\mathbf{u a}), a ́=1, \ldots, n]$ as a linear combination of neighboring observations (eq. 1):

$$
Z_{O K}^{*}(\mu)=\sum_{\alpha=1}^{n(\mu)} \lambda \alpha(\mu) Z\left(\mu_{\alpha}\right)
$$

As for other linear regression procedures, ordinary Kriging weights are chosen so as to minimize the estimation or error variance ó $2 \mathrm{E}(\mathrm{u})=\operatorname{Var}\left[\mathrm{Z}^{*}(\mathrm{u})-\mathrm{Z}(\mathrm{u})\right]$ under the constraint of an unbiased procedure of the estimator. These weights are obtained by solving a system of linear equations (eq. 2):

$$
\begin{gathered}
\sum_{\beta=1}^{n(\mu)} \lambda \beta(\mu) \gamma\left(\mu_{\alpha}-\mu_{\alpha \beta}\right)-\mu(\mu)=\gamma\left(\mu_{\alpha}-\mu\right) \\
\alpha=1, \ldots \ldots \ldots \ldots, n(u) \\
\sum_{\beta=1}^{n(u)} \lambda_{\beta}(u)=1
\end{gathered}
$$

Unbiased estimation is ensured by constraining the weights to sum to one, which requires the definition of the Lagrange parameter $\mathrm{n}(\mathbf{u})$. Semi-variogram values for different lags are derived from the semi-variogram model fitted to experimental values. The error variance was computed as (eq. 3):

$$
\sigma_{o k}^{2}(u)=\sum_{\alpha=1}^{n(u)} \lambda \alpha(u) \gamma\left(u_{\alpha}-u\right)-u(u)
$$

Under stringent hypotheses of normality and homoscedasticity, the Kriging variance was combined with the estimated value to derive a confidence interval of $95 \%$ as (eq. 4 ): 


$$
\operatorname{Prob}\left(Z(u) \in\left[Z_{o K}^{*}(u)-2 \sigma_{O K}(u), Z_{O K}^{*}(u)-2 \sigma_{O K}(u)\right]=0.95\right.
$$

\section{Results and Discussion}

\section{Land capability}

The outputs of the model were linked, to the GIS modeling environment using relational database fields which have identified key attribute property through matching tables to obtain the final maps for land capability in the studied areas (Fig. 5, 6, 7 and 8). The results of the capability model revealed the following:

a. Lands of capability order (C1) were not included in the entire studied soils in all developmental areas

b. Lands of capability order (C2) include soils of development areas in Asyut Governorate only. These lands present a good capability and can be managed with little difficulty. The main limitations of these lands with $\mathrm{C} 2$ capability class are soils, erosion risks, and bioclimatic deficiency. These lands require good and proper management. Under good management, they are moderately high to high in productivity for a fair range of crops.

c. Lands of capability order (C3) include the entire soil types of the development areas. These lands have moderate capability and moderately severe limitations that restrict the range of crops and require special conservation practices. The main limitations of these lands differed from soil, erosion risks, and bioclimatic deficiency. Similar lands have low to fair productivity for fair range of crops and improvement practices can be feasible.

d. Lands of capability orders (C4 and C5):

A land of capability orders (C4 and C5) includes different development areas. These lands have of marginal capability and very severe limitations that restricts their use for arable culture. The main limitations of these lands with $\mathrm{C} 4$ and C5 capability classes are soil depth, texture and ECe and bioclimatic deficiency. These lands have low to marginal productivity and recommended for producing forage crops, forestry and Agroforestry systems. 


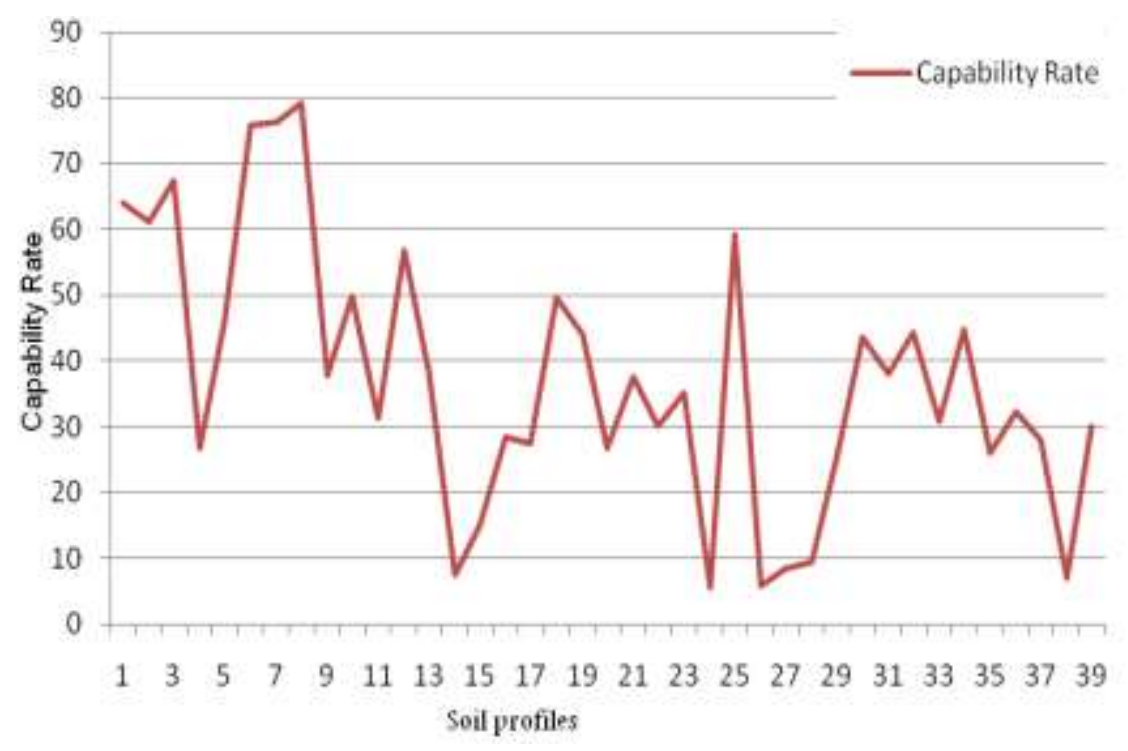

Fig. 5. Capability rate for different soil profiles in different development areas.

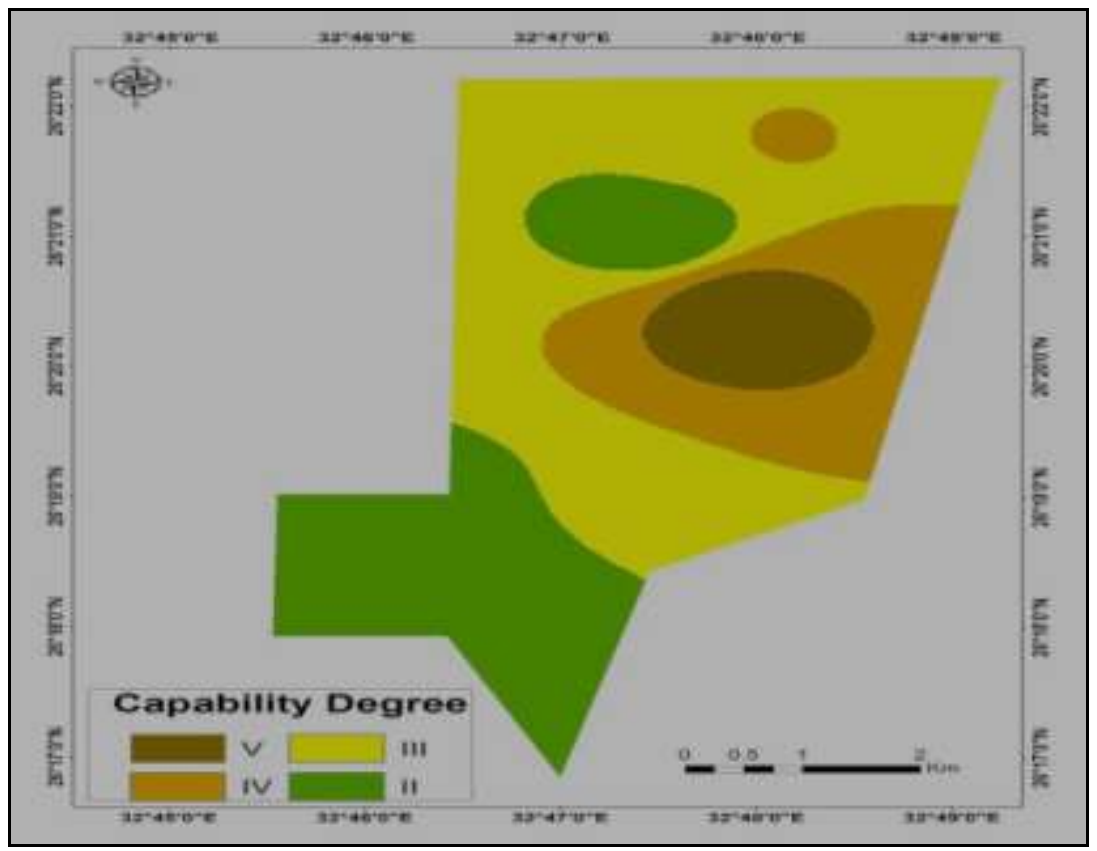

Fig. 6. Capability for development area in Wadi Qena (Qena Governorate). 


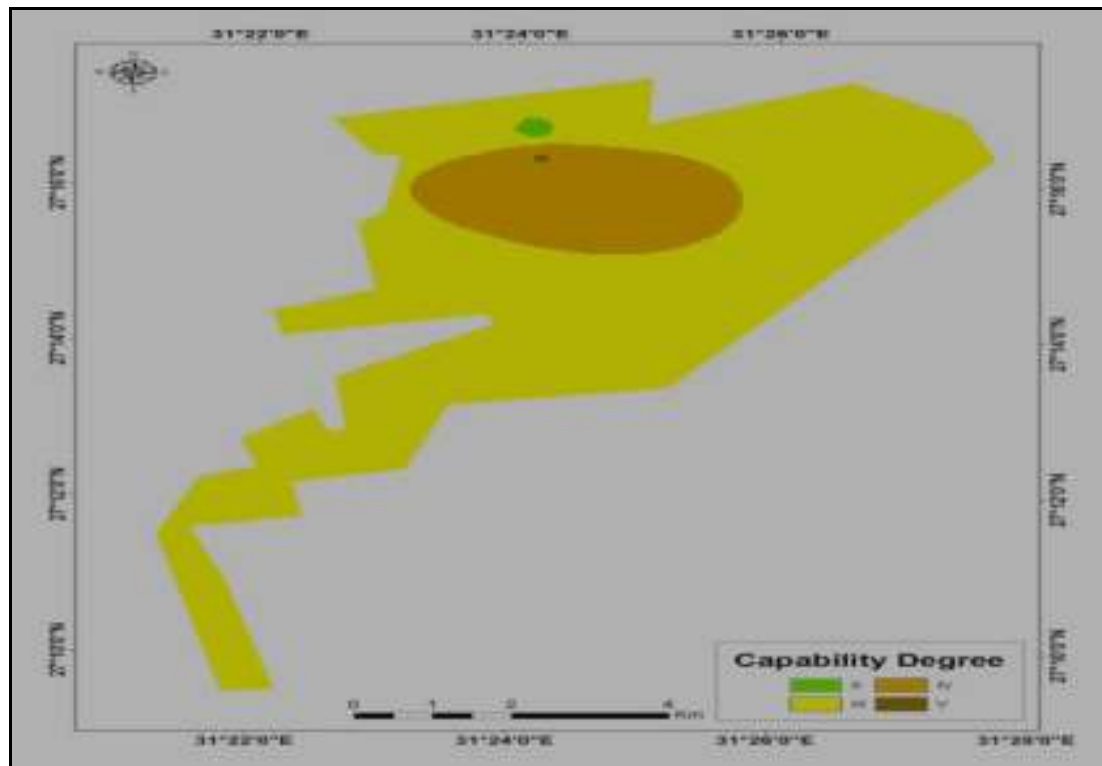

Fig. 7. Capability map for development area in Wadi Asyuty (Asyut Governorate).

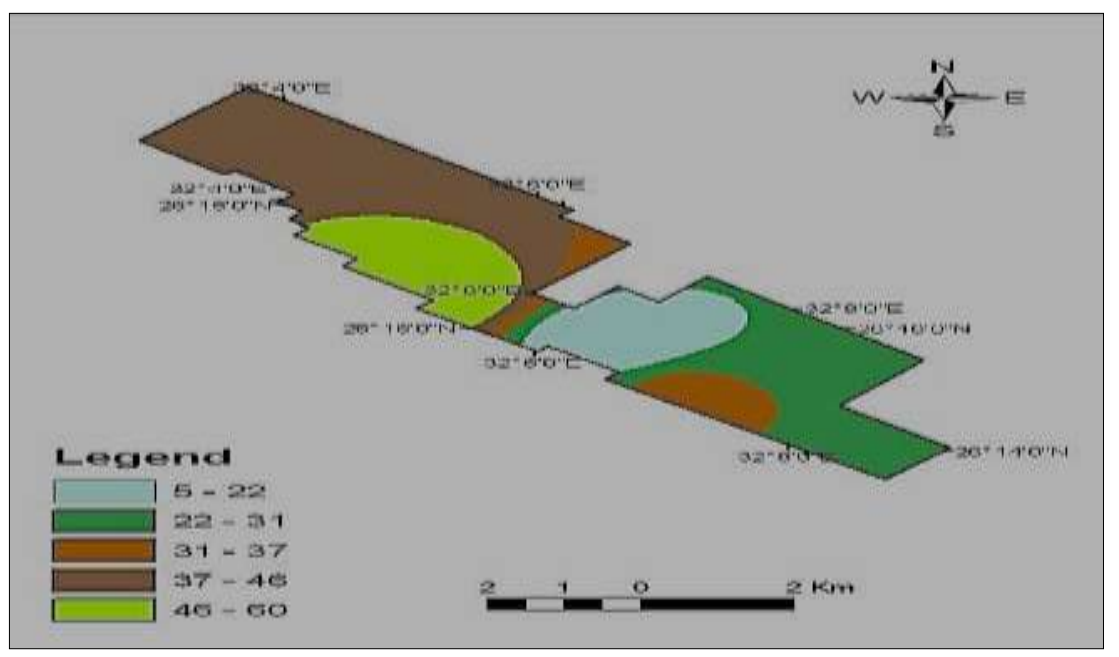

Fig. 8. Capability map for development area in Sohag Governorate .

\section{Land Suitability}

The ALES Land Suitability model used a Decision Support System (DSS) to stand on the main factor (s) that govern the soil suitability and productivity. The ALES Land Suitability model is based on crop suitability that affected by potentiality of the environment (i.e., The dominant soil characteristics). The overall soil suitability of a soil component (unit) was assessed through the maximum limitation method. The suitability is taken from the most limiting

Egypt. J. Soil Sci. 54, No. 3 (2014) 
factor of soil characteristics. Twelve traditional crops are considered as follows: cotton, wheat, potato and sunflower as annuals; alfalfa as semiannual; and citrus fruits and olive as perennials. These crops were selected to be evaluated on the available soil conditions of the study area under investigation. The outputs of the model were linked, to the GIS modeling environment using relational database fields which have identified key attribute property through matching tables to obtain the final maps for land suitability classes of study areas. Fig. 9, $10,11,12,13$ and 14 were selected to show the spatial distributions for suitability of some selected crops. The results of the suitability model revealed the following:

a. Land suitability of selected field crops: Table 1 shows that the wheat is highly to moderate (from S1 to S3) suitable in the different development areas. Cotton is highly to permanent not suitable (from S1 to S6) for the different development areas. Maize showed suitability similar to cotton crops. The main limitations of these lands with S3 to S6 suitability classes are texture, soil depth and soil salinity.

b. Land suitability of selected vegetable crops: Potato and tomato were selected for evaluation the suitability for agriculture in the different development areas. The suitability of potato ranges from moderately high to permanent not suitable (S2 to S6) (Table 2). The suitability of tomato is highly to permanent not suitable (S1 to S6). In general the potato in most developed areas is not suitable. The main limitations of these lands with suitability class are texture, soil depth and soil salinity.

c. Land suitability of selected fruits: Table 3 shows that the citrus is not permanent suitable for cultivation in the different development areas. The date palm and olive tree suitability ranged from highly to permanent not suitable (S1 to S6). In general the two fruit crops are suitable for cultivation in different development areas. The main limitations of these lands with S3 and S4 suitability classes are texture, soil depth and soil salinity.

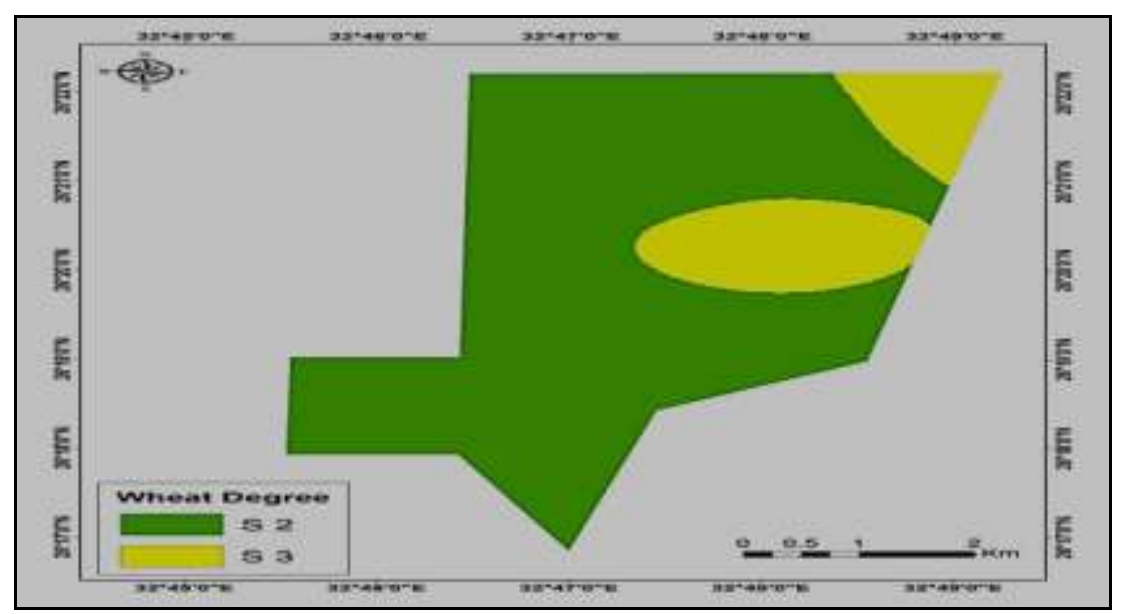

Fig. 9. Suitability map for wheat in the development area in Qena Governorate. 


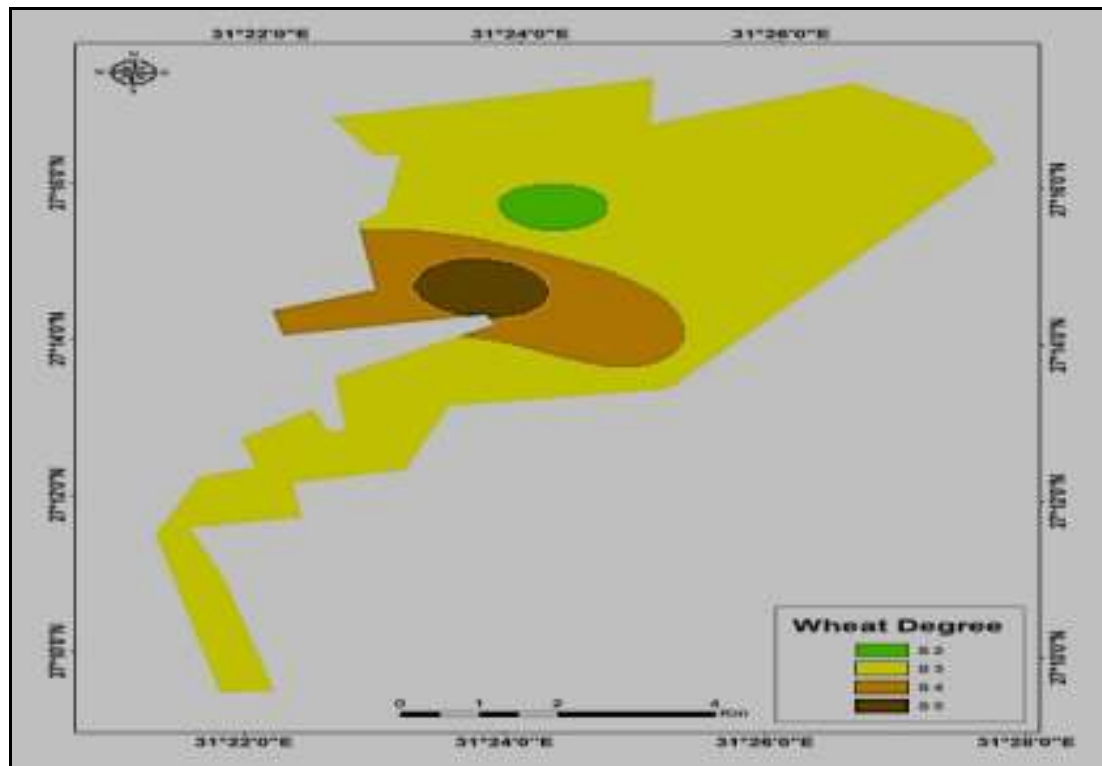

Fig. 10. Suitability map for wheat in the some development area in Asyut Governorate.

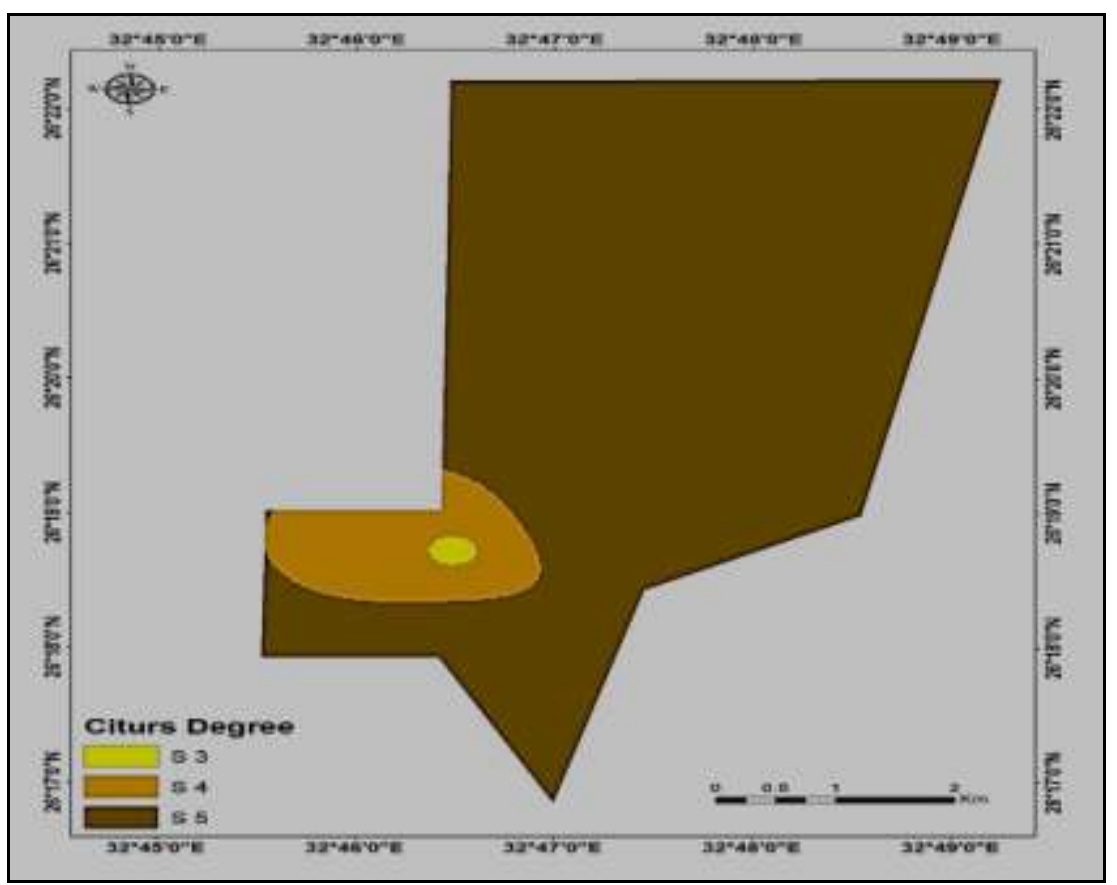

Fig. 11. Suitability map for Citrus in the some development area in Qena Governorate .

Egypt. J. Soil Sci. 54, No. 3 (2014) 


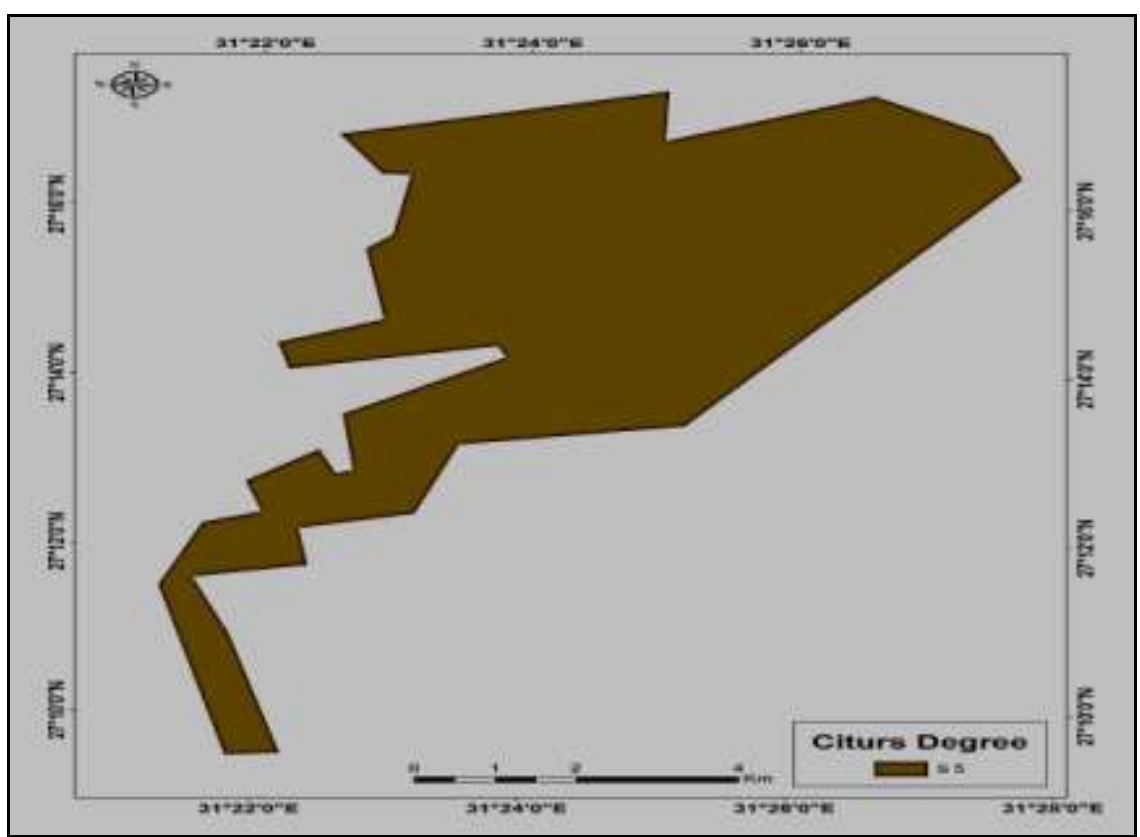

Fig. 12. Suitability map for Citrus in the some development area in Asyut Governorate .

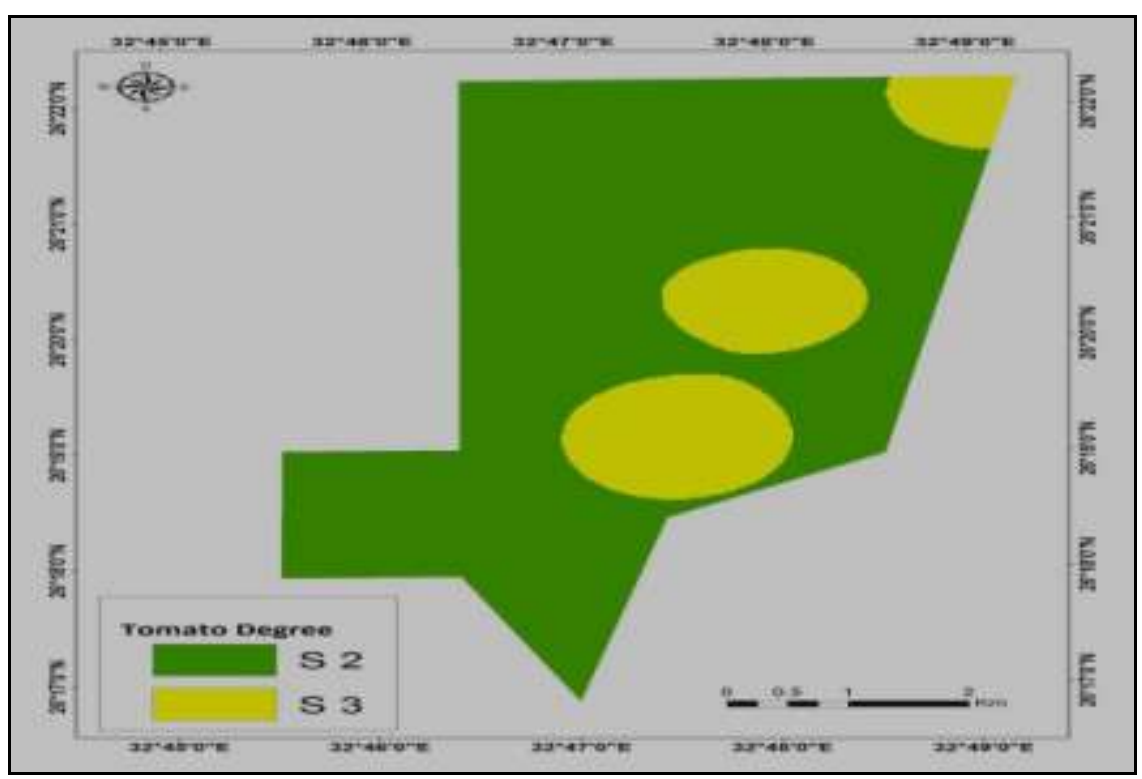

Fig. 13. Suitability map for tomato in the some development area in Qena Governorate . 


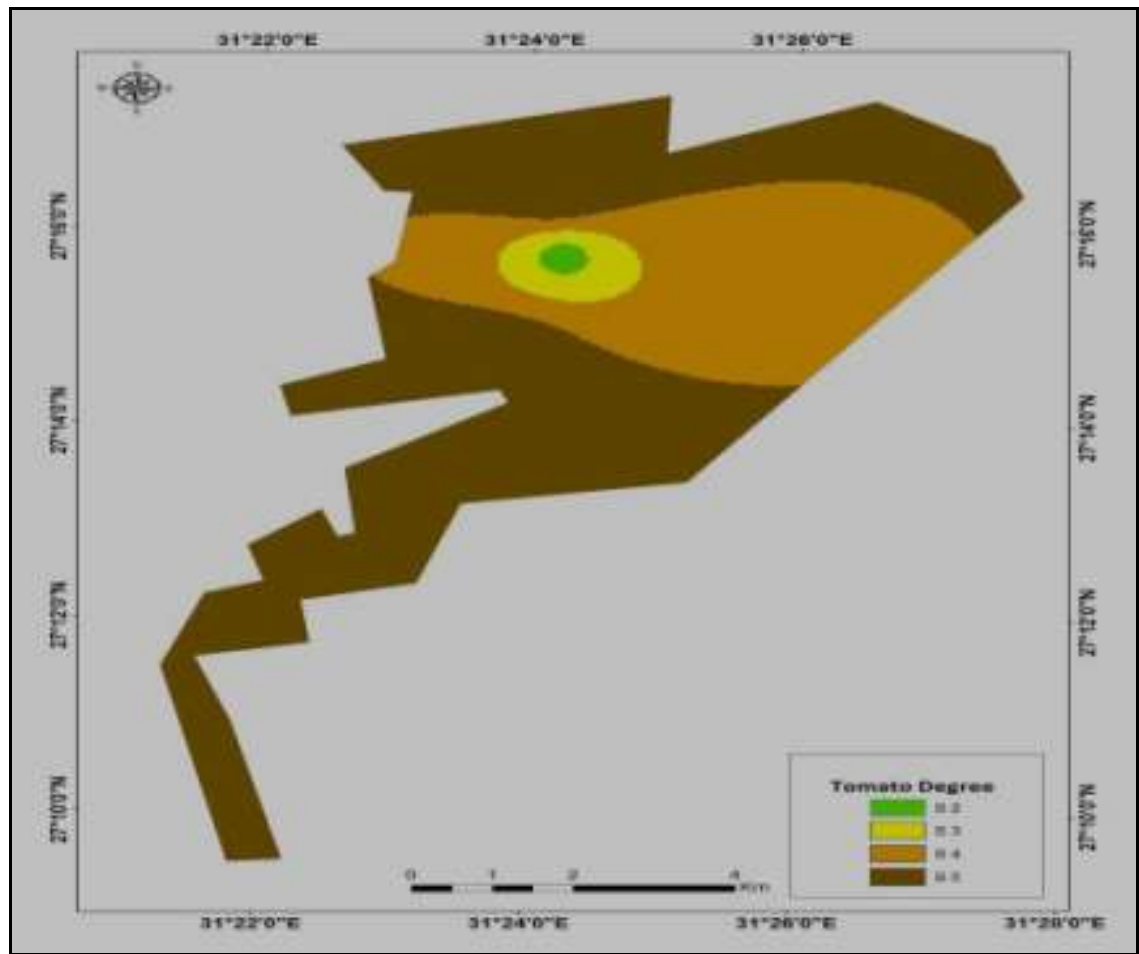

Fig. 14. Suitability map for tomato in the some development area in Asyut Governorate .

\section{Conclusion}

Application of GIS and ALES software for land evaluation targeting land use planning and decision making in sustainable agriculture, has been reached significant results and effective tools.

The set of maps, especially recommended land suitability map, of agriculture expansion in some areas of the Egypt Eastern Desert is a very helpful database not only for decision-makers, but also farmers to decide what kinds of crops should be used avoiding competition between themselves. 
EVALUATION OF SOME AGRICULTURAL EXPANSION AREAS...

TABLE 1. Land suitability for selected field crops.

\begin{tabular}{|c|c|c|c|c|c|c|c|}
\hline $\begin{array}{c}\text { Profile } \\
\text { No }\end{array}$ & $\begin{array}{c}\text { Development } \\
\text { areas } \\
\text { for agriculture }\end{array}$ & $\begin{array}{c}\text { Wheat } \\
\text { suitability } \\
\text { (Degree) }\end{array}$ & $\begin{array}{c}\text { Wheat } \\
\text { suitability } \\
\text { (Rate) }\end{array}$ & $\begin{array}{c}\text { Cotton } \\
\text { suitability } \\
\text { (Degree) }\end{array}$ & $\begin{array}{c}\text { Cotton } \\
\text { suitability } \\
\text { (Rate) }\end{array}$ & $\begin{array}{c}\text { Maize } \\
\text { suitability } \\
\text { (Degree) }\end{array}$ & $\begin{array}{c}\text { Maize } \\
\text { suitability } \\
\text { (Rate) }\end{array}$ \\
\hline 1 & \multirow{22}{*}{$\begin{array}{c}\text { Asyut } \\
\text { Governorate }\end{array}$} & S1 & 98.49 & S1 & 95.41 & S1 & 88.78 \\
\hline 2 & & S1 & 97.54 & S1 & 96.46 & S1 & 81.11 \\
\hline 3 & & S1 & 87.79 & S1 & 86.04 & S2 & 65.38 \\
\hline 4 & & S3 & 52.44 & S3 & 50.23 & S3 & 42.65 \\
\hline 5 & & S2 & 62.5 & S2 & 66.9 & S3 & 56.26 \\
\hline 6 & & S1 & 99.4 & S1 & 94.7 & S2 & 79.66 \\
\hline 7 & & S1 & 96.22 & S1 & 97.76 & S1 & 82.21 \\
\hline 8 & & S1 & 91.98 & S1 & 91.59 & S2 & 77.01 \\
\hline 9 & & S3 & 55.12 & S2 & 70.14 & S3 & 52.36 \\
\hline 10 & & S2 & 69.95 & S2 & 74.85 & S3 & 56.32 \\
\hline 11 & & S2 & 72.93 & S2 & 64.98 & S3 & 55.18 \\
\hline 12 & & S2 & 76.19 & S2 & 75.8 & S2 & 63.18 \\
\hline 14 & & S3 & 49.01 & S3 & 53.72 & S6 & 3.77 \\
\hline 15 & & S3 & 56.5 & S6 & 0.69 & S6 & 0.25 \\
\hline 16 & & S2 & 68.64 & S5 & 10.98 & S3 & 47.13 \\
\hline 17 & & S6 & 3.99 & S6 & 3.21 & S6 & 3.86 \\
\hline 18 & & S3 & 53.18 & S5 & 10.42 & S6 & 4.23 \\
\hline 19 & & S2 & 64.78 & S2 & 67.31 & S3 & 47.6 \\
\hline 20 & & S2 & 61.25 & S3 & 56.47 & S3 & 55.13 \\
\hline 21 & & S3 & 50.48 & S3 & 55.66 & S6 & 3.36 \\
\hline 22 & & S3 & 58.4 & S2 & 61.4 & S6 & 3.8 \\
\hline 23 & & S3 & 59.79 & S6 & 4.38 & S6 & 3.25 \\
\hline 24 & \multirow{8}{*}{ Sohag Governorate } & S2 & 60.23 & S3 & 59.66 & S3 & 44.26 \\
\hline 25 & & S2 & 71.24 & S5 & 12.4 & S3 & 54.14 \\
\hline 26 & & S1 & 91.84 & S2 & 78.45 & S2 & 62.54 \\
\hline 27 & & S6 & 3.15 & S6 & 3.77 & S6 & 0.27 \\
\hline 28 & & S6 & 3.46 & S6 & 2.59 & S6 & 0.25 \\
\hline 29 & & S3 & 50.38 & S6 & 8.92 & S6 & 3.62 \\
\hline 30 & & S3 & 50.67 & S3 & 57.2 & S6 & 4.01 \\
\hline 31 & & S2 & 62.65 & S2 & 63.9 & S6 & 4.05 \\
\hline 32 & \multirow{9}{*}{ Qena Governorate } & S2 & 69.11 & S2 & 70.49 & S3 & 56.19 \\
\hline 33 & & S2 & 68.76 & S2 & 70.14 & S3 & 52.03 \\
\hline 34 & & S2 & 61.09 & S3 & 54.43 & S6 & 3.95 \\
\hline 35 & & S2 & 63.86 & S2 & 68.34 & S3 & 51.93 \\
\hline 36 & & S2 & 67.94 & S3 & 56.34 & S3 & 56.89 \\
\hline 37 & & S2 & 64.65 & S3 & 57.6 & S3 & 52.56 \\
\hline 38 & & S2 & 64.6 & S5 & 10.28 & S6 & 4.02 \\
\hline 39 & & S3 & 56.35 & S5 & 10.28 & S6 & 3.77 \\
\hline 40 & & S3 & 52.46 & S3 & 57.52 & S3 & 42.67 \\
\hline
\end{tabular}

Egypt. J. Soil Sci. 54, No. 3 (2014) 
TABLE 2. Land suitability for selected vegetable crops .

\begin{tabular}{|c|c|c|c|c|c|}
\hline $\begin{array}{l}\text { Profile } \\
\text { No }\end{array}$ & $\begin{array}{c}\text { Development areas for } \\
\text { agricultural }\end{array}$ & $\begin{array}{c}\text { Potato } \\
\text { suitability } \\
\text { (Degree) }\end{array}$ & $\begin{array}{c}\text { Potato } \\
\text { suitability } \\
\text { (Rate) }\end{array}$ & $\begin{array}{c}\text { Tomato } \\
\text { suitability } \\
\text { (Degree) }\end{array}$ & $\begin{array}{c}\text { Tomato } \\
\text { suitability } \\
\text { (Rate) }\end{array}$ \\
\hline 1 & \multirow{22}{*}{ Asyut Governorate } & S2 & 77.97 & S1 & 83.78 \\
\hline 2 & & S2 & 71.23 & S1 & 84.71 \\
\hline 3 & & S3 & 55.75 & S2 & 61.69 \\
\hline 4 & & S6 & 3.03 & S3 & 59.73 \\
\hline 5 & & S6 & 4 & S2 & 73.3 \\
\hline 6 & & S2 & 69.96 & S1 & 83.19 \\
\hline 7 & & S2 & 72.19 & S2 & 77.58 \\
\hline 8 & & S2 & 67.39 & S2 & 74.57 \\
\hline 9 & & S6 & 4.65 & S2 & 61.65 \\
\hline 10 & & S3 & 56.32 & S2 & 66.97 \\
\hline 11 & & S3 & 56.28 & S2 & 74.06 \\
\hline 12 & & S2 & 67.89 & S2 & 75.1 \\
\hline 14 & & S6 & 0.3 & S6 & 4.4 \\
\hline 15 & & S6 & 0.28 & S6 & 3.7 \\
\hline 16 & & S6 & 3.51 & S2 & 66.75 \\
\hline 17 & & S6 & 0.3 & S6 & 4.5 \\
\hline 18 & & S6 & 0.28 & S6 & 4.91 \\
\hline 19 & & S6 & 3.75 & S2 & 66.65 \\
\hline 20 & & S6 & 4.34 & S2 & 69.76 \\
\hline 21 & & S6 & 3.58 & S3 & 49.8 \\
\hline 22 & & S6 & 4.14 & S3 & 57.67 \\
\hline 23 & & S6 & 3.83 & S6 & 4.55 \\
\hline 24 & \multirow{8}{*}{ Sohag Governorate } & S6 & 3.49 & S2 & 61.98 \\
\hline 25 & & S6 & 3.47 & S2 & 73.08 \\
\hline 26 & & S3 & 53.32 & S3 & 59.01 \\
\hline 27 & & S6 & 0.32 & S6 & 0.32 \\
\hline 28 & & S6 & 0.29 & S6 & 0.29 \\
\hline 29 & & S6 & 3.4 & S6 & 4.5 \\
\hline 30 & & S6 & 4.27 & S6 & 4.73 \\
\hline 31 & & S6 & 0.32 & S3 & 59.37 \\
\hline 32 & \multirow{9}{*}{ Qena Governorate } & S3 & 55.64 & S2 & 66.17 \\
\hline 33 & & S3 & 55.36 & S2 & 72.86 \\
\hline 34 & & S6 & 0.3 & S3 & 56.33 \\
\hline 35 & & S6 & 3.7 & S2 & 61.15 \\
\hline 36 & & S2 & 60.54 & S2 & 60.54 \\
\hline 37 & & S6 & 3.74 & S2 & 61.9 \\
\hline 38 & & S6 & 4.2 & S2 & 62.54 \\
\hline 39 & & S6 & 0.77 & S3 & 59.71 \\
\hline 40 & & S6 & 3.04 & S3 & 59.76 \\
\hline
\end{tabular}

Egypt. J. Soil Sci. 54, No. 3 (2014) 
EVALUATION OF SOME AGRICULTURAL EXPANSION AREAS...

TABLE 3. Land suitability for selected fruit crops.

\begin{tabular}{|c|c|c|c|c|c|c|c|}
\hline $\begin{array}{c}\text { Profile } \\
\text { No. }\end{array}$ & $\begin{array}{l}\text { Development } \\
\text { areas for } \\
\text { agriculture }\end{array}$ & $\begin{array}{c}\text { Citrus } \\
\text { suitability } \\
\text { (Degree) }\end{array}$ & $\begin{array}{c}\text { Citrus } \\
\text { suitability } \\
\text { (Rate) }\end{array}$ & $\begin{array}{c}\text { Date Palm } \\
\text { suitability } \\
\text { (Degree) }\end{array}$ & $\begin{array}{c}\text { Date Palm } \\
\text { suitability } \\
\text { (Rate) }\end{array}$ & $\begin{array}{c}\text { Olive } \\
\text { suitability } \\
\text { (Degree) }\end{array}$ & $\begin{array}{c}\text { Olive } \\
\text { suitability } \\
\text { (Rate) }\end{array}$ \\
\hline 1 & \multirow{22}{*}{ Asyut Governorate } & S1 & 82.62 & S1 & 90.03 & S1 & 90.03 \\
\hline 2 & & S2 & 75.48 & S1 & 84.71 & S1 & 91.02 \\
\hline 3 & & S6 & 4.7 & S1 & 87.25 & $\mathrm{~S} 1$ & 87.25 \\
\hline 4 & & S6 & 0.4 & S5 & 10.18 & S5 & 10.18 \\
\hline 5 & & S6 & 2.86 & S2 & 73.32 & S2 & 79.79 \\
\hline 6 & & S2 & 74.13 & S1 & 83.19 & S1 & 89.3 \\
\hline 7 & & S2 & 64.33 & S1 & 85.8 & S1 & 92.3 \\
\hline 8 & & S3 & 58.52 & S1 & 88.68 & S1 & 95.3 \\
\hline 9 & & S6 & 3.9 & S1 & 87.19 & S2 & 69.46 \\
\hline 10 & & S6 & 3.6 & S1 & 84.02 & S1 & 84.02 \\
\hline 11 & & S6 & 7.68 & S5 & 13.5 & S5 & 13.5 \\
\hline 12 & & S3 & 48.48 & S1 & 89.6 & S1 & 96 \\
\hline 14 & & S6 & 0.2 & S2 & 65.43 & S3 & 55 \\
\hline 15 & & S6 & 0.04 & S5 & 11.35 & S5 & 10.26 \\
\hline 16 & & S6 & 0.52 & S5 & 12.59 & S5 & 12.59 \\
\hline 17 & & S6 & 0.04 & S6 & 9.64 & S6 & 0.77 \\
\hline 18 & & S6 & 0.04 & S5 & 11.32 & S6 & 9.52 \\
\hline 19 & & S6 & 3.18 & S1 & 81.64 & S1 & 81.64 \\
\hline 20 & & S6 & 3.04 & S2 & 68.78 & S2 & 68.78 \\
\hline 21 & & S6 & 3.04 & S2 & 63.64 & S2 & 63.64 \\
\hline 22 & & S6 & 3.14 & S2 & 65.6 & S2 & 67.12 \\
\hline 23 & & S6 & 2.9 & S2 & 67.12 & S2 & 67.12 \\
\hline 24 & \multirow{8}{*}{ Sohag Governorate } & S6 & 2.64 & S2 & 67.62 & S2 & 67.62 \\
\hline 25 & & S6 & 0.54 & S5 & 12.45 & S5 & 12.45 \\
\hline 26 & & S3 & 50.34 & S2 & 74.35 & S2 & 74.35 \\
\hline 27 & & S6 & 0.27 & S6 & 4.72 & S6 & 3.97 \\
\hline 28 & & S6 & 0.05 & S6 & 0.67 & S6 & 8.44 \\
\hline 29 & & S6 & 0.04 & S5 & 11.46 & S6 & 9.64 \\
\hline 30 & & S6 & 3.23 & S2 & 67.66 & S3 & 56.89 \\
\hline 31 & & S6 & 0.24 & S2 & 69.6 & S2 & 69.6 \\
\hline 32 & \multirow{9}{*}{ Qena Governorate } & S6 & 3.35 & S2 & 77.58 & S2 & 77.58 \\
\hline 33 & & S3 & 41.88 & S2 & 77.19 & S2 & 77.19 \\
\hline 34 & & S6 & 0.04 & S5 & 12.63 & S5 & 11.41 \\
\hline 35 & & S6 & 0.24 & S2 & 76.71 & S2 & 76.71 \\
\hline 36 & & S6 & 6.66 & S5 & 12.27 & S5 & 13.18 \\
\hline 37 & & S6 & 0.04 & S5 & 12.54 & S5 & 12.54 \\
\hline 38 & & S6 & 0.6 & S5 & 13.62 & S5 & 12.31 \\
\hline 39 & & S6 & 0.04 & S5 & 10.93 & S5 & 10.93 \\
\hline 40 & & S6 & 2.3 & S3 & 58.92 & S3 & 58.92 \\
\hline
\end{tabular}

Egypt. J. Soil Sci. 54, No. 3 (2014) 


\section{References}

Abd El-Kawy, O.R., Ismail, H.A., Rod, J.K. and Suliman, A.S. (2010) A Developed GIS-based Land Evaluation Model for Agricultural Land Suitability Assessments in Arid and Semi Arid Regions. Research Journal of Agriculture and Biological Sciences 6 (5): 589-599.

Abdel Rahman, M.A. and El-Taweel, M.I., (1994) Soil productivity classification of Qiman El Arus area, Beni Suef Governorate, Middle Egypt. Egypt. J. Appl. Sci. 4:577-591.

Deutsch, C.V. and Journel, A.G. (1992) GSLIB - Geostatistical Software Library and User's Guide, 338 p., Oxford University Press, New York. ESRI. (2013) Raster, vector and online GIS data resources.

FAO (Food and Agriculture Organization of the United Nations) (1984) Land evaluation for forestry. Forestry, Paper 48, FAO, Rome, Italy.

FAO (Food and Agriculture Organization of the United Nations) (1991) Guidelines: land evaluation for extensive grazing. Soils Bulletin 58, FAO, Rome, Italy.

FAO (Food and Agriculture Organization of the United Nations) (1992) The use of saline water for crop production, FAO, Rome, Italy.

FAO (Food and Agriculture Organization of the United Nations) (1976) "A Framework for Land Evaluation." Soils Bulletin 32, Rome.

Ganzorig, M.and Adyasuren, Ts. (1995) Application of RS and GIS for Ecosystem Monitoring and Management, Paper presented at the International Seminar on Space Informatics, Ulaanbaatar, Mongolia.

Ismail, H.A., Morsy, I.M., El-Zahaby, E.M. and El-Nagar, F.S. (2001) A Developed expert system for land use planting by coupling and modeling. Alex. J. Agric. Res. 46 (3): 141-154.

Oz, B. and Friedman, J. (2001) Allelopathic bacteria and their impact on higher plants. Crit. Rev. Microbiol. 27: 41-55.

Panigrahy, S., Manjunath, K.R. and Ray, S.S. (2006) Deriving cropping system performance indices using remote sensing data and GIS. Int. J. Remote Sensing 26, 2595-2606.

Rao, D.P., Gautam, N.C., Nagaraja, R. and Ram Mohan, P. (1996) IRS-IC application in land use mapping and planning. Curr. Sci. 70: 575-578.

Rossiter, D.G., (2001) A Practical Framework For Land Evaluation. Unpublished manuscript, Enschede.

Sys, C., Van Ranst, E. and Debaveye, J. (1991) Land Evaluation. Part I: Principles in Land Evaluation and Crop Production Calculations", Agric. Pub. No. 7, General Administration for Development Cooperation, Brussels.

USDA (2004) "Soil Survey Laboratory Methods Manual", Soil Survey Investigation Report No. 42, Version 4.0. 


\section{تقييم بعض مناطق التوسع الزراعي في صحراء مصر الثرقية باستخدام نظم المعلومات الجغر افئة الزية}

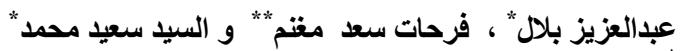

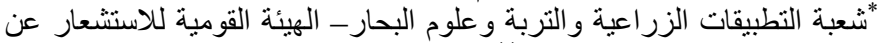

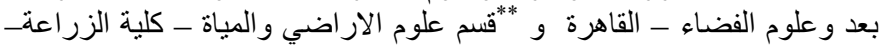
جامعة كفر الثيخ - كفر الثيخ - مصرة. ولفر

أجري تقييم للأر اضي فى مناطق التنمية الزر اعية في محافظات أسيوط ، سو هاج

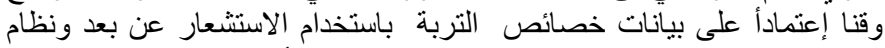

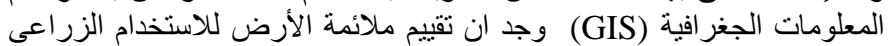

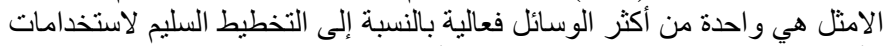

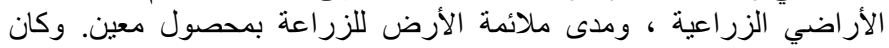

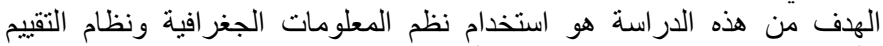

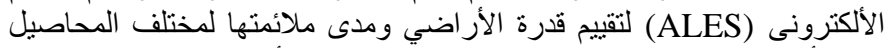

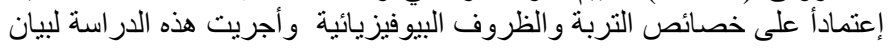

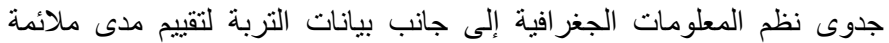
المحاصيل للزر اعة لتحقيق نظم الزر اعة المستدامة في منطقة الدر استة التهات

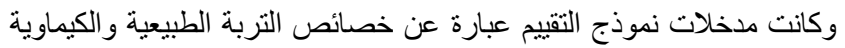

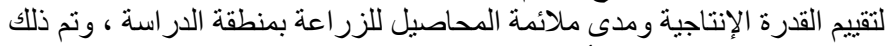

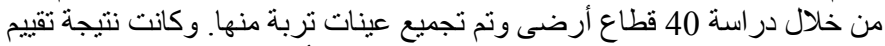

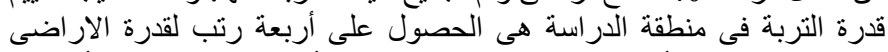

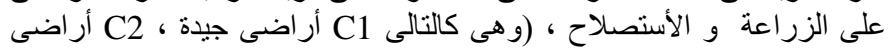

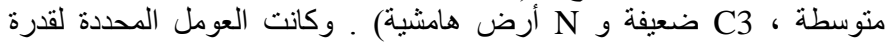
الارض الإنتاجية هى التضاريس (t) ) ، وخصائص التربة (1) هائة (1) ، ومخاطر التعرية

(b) و المناخ الإناجية (r)

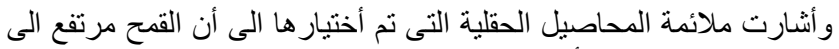

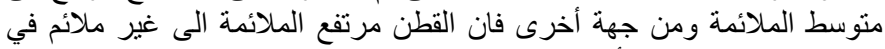

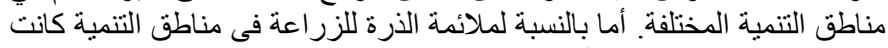

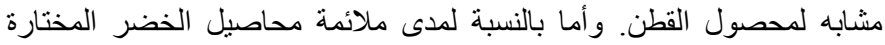

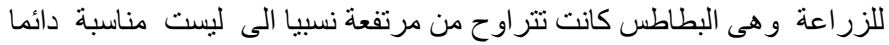

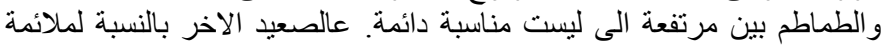

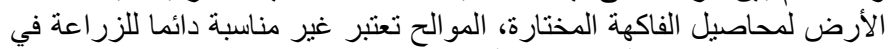

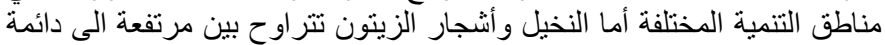
غير مناسبة للزر اعة. 